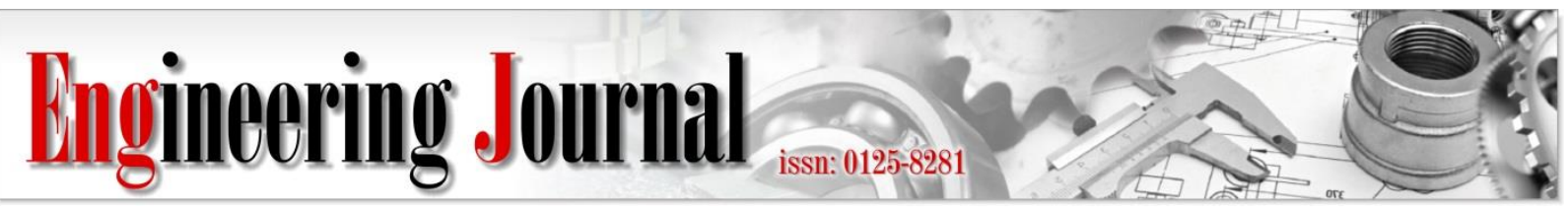

Article

\title{
Corrosion Resistance of Modified Heat-Treated 16Cr- 4Ni Steel for Geothermal Steam Turbine Blades
}

\author{
Li-Bin Niu ${ }^{1, *}$, Yang Xiao ${ }^{2}$, Sakae Izumi ${ }^{3}$, Kunio Shiokawa ${ }^{3}$, Mitsuo Yamashita $^{3}$, \\ and Yoshihiro Sakai \\ 1 Institute of Engineering, Academic Assembly, Shinshu University, 4-17-1 Wakasato, Nagano 380-8553, \\ Japan \\ 2 Graduate Student of Shinshu University; present: Orion Mach. Co., Ltd., Suzaka City, Nagano 382-8502, \\ Japan \\ 3 Fuji Electric Co., Ltd., Kawasaki-ku, Kawasaki City, Kanagawa 210-9530, Japan \\ *E-mail: niulibn@shinshu-u.ac.jp (Corresponding author)
}

\begin{abstract}
Immersion corrosion tests and electrochemical corrosion tests were carried out in the simulated geothermal water on a modified heat-treated material of $16 \mathrm{Cr}-4 \mathrm{Ni}$ steel, which is used for geothermal steam turbine blades. Incidentally, the purpose of the modified heat treatment is for reducing the susceptibility of stress corrosion cracking (SCC) of the steel in the geothermal fluids. For comparison, a conventional heat-treated material of the $16 \mathrm{Cr}-4 \mathrm{Ni}$ steel was also used in the corrosion tests. In the immersion corrosion tests up to 4,000 hours, the modified heat-treated material showed lower corrosion rates than those of the conventional heat-treated one in the test water. In the electrochemical corrosion tests, the modified heat-treated material exhibited noble and stable corrosion potential behavior. The XPS analysis results exhibited that the passive films formed on the materials were consisted mainly of $\mathrm{Cr}$-oxides $\left(\mathrm{CrOOH}, \mathrm{CrO}_{3}\right)$ and Fe-oxides $\left(\mathrm{FeO}, \mathrm{Fe}_{2} \mathrm{O}_{3}\right)$. Furthermore, the composition ratio of Cr-oxides in the outermost surface of the passive film formed on the modified heat-treated material was higher than that on the conventional heat-treated one. It was suggested that the better corrosion resistance of the modified heat-treated $16 \mathrm{Cr}$ $4 \mathrm{Ni}$ steel was contributed to the formation of the passive film with higher compositions of Cr-oxides.
\end{abstract}

Keywords: Geothermal steam turbine, corrosion, $16 \mathrm{Cr}-4 \mathrm{Ni}$ steel, corrosion rate, open circuit potential, passive film.

ENGINEERING JOURNAL Volume 23 Issue 4

Received 3 May 2019

Accepted 12 July 2019

Published 8 August 2019

Online at http://www.engj.org/

DOI:10.4186/ej.2019.23.4.213 


\section{Introduction}

In geothermal power plants, the equipment materials are easily subject to general corrosion, pitting corrosion, stress corrosion cracking (SCC) and so on, due to large amounts of corrosive chemicals such as carbon dioxide $\left(\mathrm{CO}_{2}\right)$, chloride $(\mathrm{Cl})$ and sulfate $\left(\mathrm{SO}_{4}{ }^{2-}\right)$ contained in the geothermal fluids [1]. Therefore, evaluation on the corrosion behavior of the components is one of the important subjects [2, 3, 4]. In order to improve the reliability and economic efficiency of geothermal power plants, various surface modifications for enhancing the corrosion resistance and the appropriate selection of equipment materials and so on are being carried out $[5,6]$.

Even in the steam turbine environments of fossil and nuclear power plants, where the concentration of corrosive chemicals is extremely low, the steam turbine materials also experience pitting corrosion and subsequent SCC [7, 8, 9, 10, 11]. 13 Cr and 12Cr martensitic stainless steels have been widely used as blade materials for steam turbines of fossil and nuclear power plants. However, the embrittlement has been one of the subjects of the steels. It has been reported that the sensitivity to embrittlement of the $13 \mathrm{Cr}$ martensitic stainless steels increases by tempering in the temperature range $400-575^{\circ} \mathrm{C}$ with a maximum at $550^{\circ} \mathrm{C}$, while it decreases with further increases in tempering temperatures [12]. SCC susceptibility of the $13 \mathrm{Cr}$ martensitic stainless steels has also been evaluated in corrosive environments. Ozaki et al. [13] have reported that the SCC susceptibility increases with increasing hardness of the steels. They have also reported that the nickel containing 13Cr martensitic stainless steels tempered at lower temperatures showed higher hardness but their SCC susceptibility increased $[14,15]$. It was therefore suggested that high temperature tempering is effective to lower the SCC susceptibility of the steels [15].

On the other hand, $16 \mathrm{Cr}-4 \mathrm{Ni}$ (also called 17-4PH) precipitation hardening stainless steels have also been used as the steam turbine blade materials for power plants because of their balanced combination of good mechanical properties and adequate corrosion resistance $[16,17]$. For the same reason, the $16 \mathrm{Cr}-4 \mathrm{Ni}$ steels have also been used for geothermal steam turbine blades. Sakai et al. [2] have conducted SCC tests and corrosion fatigue tests on the $16 \mathrm{Cr}-4 \mathrm{Ni}$ precipitation hardening stainless steels with different heat treatments. It has been reported that a modified heat-treated material of the $16 \mathrm{Cr}-4 \mathrm{Ni}$ steels has not only higher Charpy absorbed energy but also higher SCC resistance and higher corrosion fatigue strength in the simulated geothermal fluids [2]. It has been expected that the modified heat treatment should be the suitable condition for the $16 \mathrm{Cr}-4 \mathrm{Ni}$ steels for geothermal steam turbine blades. However, the knowledge about the corrosion resistance of the modified heat-treated $16 \mathrm{Cr}-4 \mathrm{Ni}$ steel has not been obtained yet sufficiently.

In this study, immersion corrosion tests and electrochemical corrosion tests were carried out in the simulated geothermal water on the modified heat-treated $16 \mathrm{Cr}-4 \mathrm{Ni}$ steel, which is used for geothermal steam turbine blades. For comparison, a conventional heat-treated material of the steel was also used in the corrosion tests. The corrosion resistance of the modified heat-treated $16 \mathrm{Cr}-4 \mathrm{Ni}$ steel was evaluated based on the corrosion test results and on the characteristics of the passive film formed on the specimen surfaces.

\section{Experimental}

\subsection{Materials and Specimens}

The chemical composition of the $16 \mathrm{Cr}-4 \mathrm{Ni}$ steel $(17-4 \mathrm{PH}$ precipitation hardened stainless steel) used in this work is given in Table 1. The modified heat treatment for reducing the SCC susceptibility was performed on the materials for steam turbine blades of geothermal power plants. After solution treatment at $1038^{\circ} \mathrm{C}$, the materials were subjected to two-steps tempering treatments at $835^{\circ} \mathrm{C}$ for 1 hour and then at $620^{\circ} \mathrm{C}$ for 3 hours. The modified heat-treated material is simply named " $\mathrm{D} 2$ " in the present work. For comparison, conventional heat-treated materials of the 16Cr-4Ni steel (named "D1"), which are used for the steam turbine blades of fossil and nuclear power plants, were also used. Table 2 shows the two kinds of heat treatment. The Vickers hardness of the heat-treated materials D2 and D1 are HV413 and HV437, respectively. It has been reported that the modified heat-treated material D2 with lower hardness has higher SCC resistance than the conventional heat-treated material D1 [2].

The specimens with a size of $40 \times 15 \times 2 \mathrm{~mm}^{3}$ were cut from the heat-treated virgin materials for steam turbine blades, and were abraded using 150-800 grit emery papers. Prior to corrosion testing, the specimens were degreased with acetone and rinsed with pure water. 
Table 1. Chemical composition of $16 \mathrm{Cr}-4 \mathrm{Ni}$ steel.

\begin{tabular}{c|c|c|c|c|c|c|c|c|c}
\hline $\mathbf{C}$ & $\mathbf{S i}$ & $\mathbf{M n}$ & $\mathbf{P}$ & $\mathbf{S}$ & $\mathbf{N i}$ & $\mathbf{C r}$ & $\mathbf{M o}$ & $\mathbf{C u}$ & $\mathbf{F e}$ \\
\hline 0.038 & 0.27 & 0.36 & 0.014 & 0.001 & 4.32 & 15.61 & 0.08 & 3.10 & Bal. \\
\hline
\end{tabular}

Table 2. Heat treatment of the materials used in corrosion tests.

\begin{tabular}{c|c|c}
\hline Material & $\begin{array}{c}\text { D2 } \\
\text { (Modified heat treatment) }\end{array}$ & $\begin{array}{c}\text { D1 } \\
\text { (Conventional heat treatment) }\end{array}$ \\
\hline \multirow{3}{*}{ Heat treatment } & $1038^{\circ} \mathrm{C} \times 1$ hour AC & $1038^{\circ} \mathrm{C} \times 1$ hour AC \\
& $835^{\circ} \mathrm{C} \times 1$ hour AC & $580^{\circ} \mathrm{C} \times 3$ hours AC \\
\hline
\end{tabular}

AC: Air Cooling

Table 3. Quality of the test water.

\begin{tabular}{|c|c|c|c|c|c|c|}
\hline \multicolumn{3}{|c|}{ Corrosive impurities } & \multirow{2}{*}{$\begin{array}{c}\text { Electric } \\
\text { conductivity } \\
{[\mathrm{mS} / \mathrm{m}]}\end{array}$} & \multirow{2}{*}{$\mathrm{pH}$} & \multirow{2}{*}{$\begin{array}{c}\text { DO } \\
{[\mathrm{ppm}]}\end{array}$} & \multirow{2}{*}{$\begin{array}{c}\text { Temp. } \\
{\left[{ }^{\circ} \mathrm{C}\right]}\end{array}$} \\
\hline $\mathrm{Cl}^{-}[\mathrm{ppm}]$ & $\mathrm{SO}_{4}^{2-}[\mathrm{ppm}]$ & $\mathrm{CO}_{2}$ & & & & \\
\hline 10,000 & 50 & Bubbling & 2.68 & 5.05 & $0.1 \sim 0.2$ & 90 \\
\hline
\end{tabular}

\subsection{Test Water}

Geothermal fluids are generally accompanied by the non-condensable gases such as $\mathrm{CO}_{2}$, hydrogen sulphide $\left(\mathrm{H}_{2} \mathrm{~S}\right)$, etc., and the dissolved corrosive impurities such as $\mathrm{Cl}^{-}, \mathrm{SO}_{4}{ }^{2-}$, etc. [2]. The quality and the temperature of geothermal fluids vary from site to site. In this work, considering the equipment materials in the severe corrosive phase transition zone (PTZ) of geothermal steam turbines, an accelerated corrosive environment of the geothermal water was simulated as the test water. As shown in Table 3, the test water was prepared from ion-exchanged pure water by adding the impurity ions of $10,000 \mathrm{ppm} \mathrm{Cl}^{-}$and $50 \mathrm{ppm} \mathrm{SO}_{4}^{2-}$, and by continuously bubbling $\mathrm{CO}_{2}$ gas into the water before and during test. In addition, the $\mathrm{Cl}^{-}$and $\mathrm{SO}_{4}{ }^{2-}$ were added as $\mathrm{NaCl}$ and $\mathrm{Na}_{2} \mathrm{SO}_{4}$, respectively. The temperature of the test water was $90^{\circ} \mathrm{C}$.

\subsection{Immersion Corrosion Test}

Using a water-loop type corrosion test equipment, immersion tests were carried out on the D2 and D1 specimens in the test water. The immersion times were 500 hours, 2,000 hours and the longest of 4,000 hours. Two specimens were used for the same immersion test condition.

After immersion tests, the specimens were observed with a digital camera and an optical microscope $(\mathrm{OM})$. After that, descaling of the films formed on the specimens in the test water was performed, and the corrosion rates of the specimens were calculated from the following Eq. (1) [18]. In addition, the descaling was performed by electrolytic removal in a 10\% di-ammonium hydrogen citrate aqueous solution for 1 hour, using a platinum electrode as a counter electrode at a current density of $0.14 \mathrm{~A} / \mathrm{cm}^{2}$.

$$
\dot{W}=\frac{\Delta W}{S \cdot \Delta t}=\frac{\left(W_{1}-W_{2}-b\right)}{S \cdot \Delta t}
$$

where,

$\dot{W}\left[\mathrm{mdd} ; \mathrm{mg} \cdot \mathrm{dm}^{-2} \cdot \mathrm{day}^{-1}\right]:$ corrosion rate

$\Delta W[\mathrm{mg}]:$ corrosion amount

$W_{1}[\mathrm{mg}]$ : specimen mass before test

$W_{2}[\mathrm{mg}]$ : specimen mass after descaling 
$S\left[\mathrm{dm}^{2}\right]$ : surface area of a specimen

$\Delta t$ [day]: immersion time

$b[\mathrm{mg}]$ : blank correction for the loss due to descaling

\subsection{Electrochemical Corrosion Test and Analysis of Specimen Surface}

Open circuit potential (OCP) measurements were conducted using a potentiostat with three electrodes: a working electrode of the specimen, a platinum counter electrode, and a saturated $\mathrm{KCl}-\mathrm{Ag} / \mathrm{AgCl}$ reference electrode. The OCP of each specimen in the test water was continuously measured for 20 hours.

After OCP measurements, the specimen surfaces were observed with a scanning electron microscope (SEM). The films formed on the specimens in the test water were analyzed by X-ray photoelectron spectroscopy (XPS). The XPS analyses were carried out using monochromatic Al-K $\alpha$ radiations at 1486.92 $\mathrm{eV}$. To calculate the compositions of the films, calibration of the XPS spectra was performed with reference to the peak area and the intensity factor $\sigma$ of the elements: $\sigma(\mathrm{Fe} 2 \mathrm{p} 3 / 2)=10.82, \sigma(\mathrm{Cr} 2 \mathrm{p} 3 / 2)=7.69$, $\sigma(\mathrm{Ni} 2 \mathrm{p} 3 / 2)=14.61$, and $\sigma(\mathrm{O} 1 \mathrm{~s})=2.93$. The compositions of the films formed were identified through wave form analysis with reference to standard XPS peak data [19].

\section{Results and Discussion}

\subsection{Corrosion Rate}

As examples, the appearances of the 4,000 hours immersed specimens and those after descaling are shown in Fig. 1. Both of the two specimens of D1 and D2 showed ocher color after the 4,000 hours immersion tests, while they exhibited still metallic luster with no obvious corrosion on the surfaces after descaling. It was confirmed that even in the present test water with the added large amount of corrosive impurities both the two heat-treated materials of the $16 \mathrm{Cr}-4 \mathrm{Ni}$ steel have adequate corrosion resistance.

As mentioned above, for each heat-treated steel two specimens were used in the corrosion test for the same immersion time. It is necessary to note additionally that it should be desirable to set the number of specimens to 3 or more at each immersion time to improve statistical significance [20]. In the present work, the tendency of corrosion resistance up to 4,000 hours was investigated with a small number of specimens. The corrosion rates of the specimens in the test water were listed in Table 4. The average corrosion rates are plotted in Fig. 2. As shown in this figure, the D2 specimens with the modified heat treatment showed higher corrosion rates up to 2,000 hours immersion tests. However, their corrosion rates showed a decreasing tendency, which was different with those of the D1 specimens. Furthermore, the average corrosion rate of the D2 specimens immersed up to 4,000 hours showed a smaller value than that of the D1 specimens. It is therefore considered that the modified heat-treated material has better corrosion resistance for a longer service term than the conventional heat-treated one of the $16 \mathrm{Cr}-4 \mathrm{Ni}$ steel.

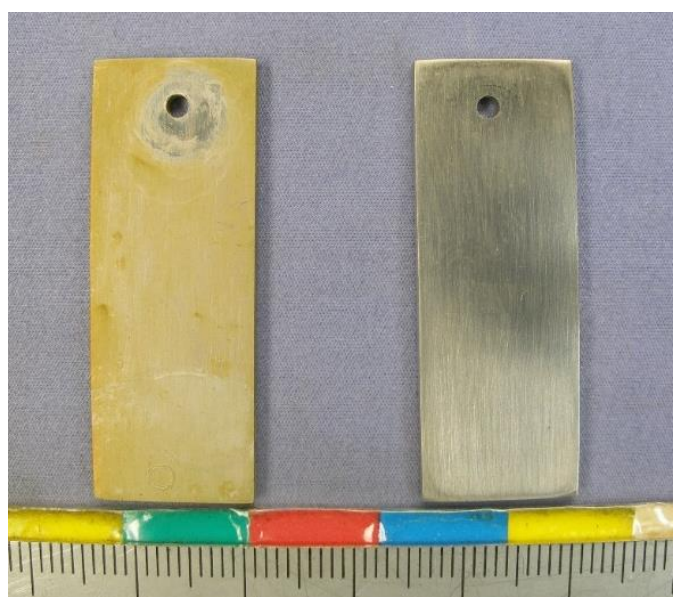

As-immersed
After descaling

(a) D1

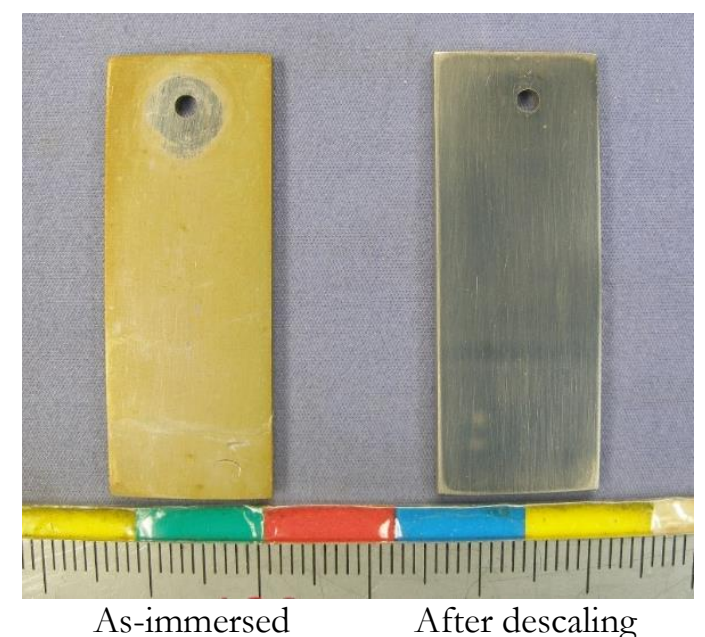

(b) $\mathrm{D} 2$

Fig. 1. Appearances of the 4,000 hours immersed specimens and those after descaling. 
Table 4. Corrosion rates of the specimens in immersion tests.

\begin{tabular}{c|c|c|c|c}
\hline Material & Specimen & $\mathbf{5 0 0}$ hours & $\mathbf{2 , 0 0 0}$ hours & $\mathbf{4 , 0 0 0}$ hours \\
\hline \multirow{5}{*}{ D1 } & No.1 & 0.01915 & & \\
\cline { 2 - 5 } & No.2 & 0.03268 & & \\
\cline { 2 - 5 } & No.3 & & 0.05014 & \\
\cline { 2 - 5 } & No.4 & & 0.02085 & \\
\cline { 2 - 5 } & No.5 & & & 0.05465 \\
\cline { 2 - 5 } & No.6 & & & 0.07535 \\
\cline { 2 - 5 } & Average & 0.02592 & 0.03549 & 0.06500 \\
\hline \multirow{5}{*}{ D2 } & No.1 & 0.09127 & & \\
\cline { 2 - 5 } & No.2 & 0.02147 & & \\
\cline { 2 - 5 } & No.3 & & 0.05352 & \\
\cline { 2 - 5 } & No.4 & & 0.03268 & \\
\cline { 2 - 5 } & No.5 & & & 0.04113 \\
\cline { 2 - 5 } & No.6 & & & 0.03465 \\
\cline { 2 - 5 } & Average & 0.05634 & 0.04310 & 0.03789 \\
\hline
\end{tabular}

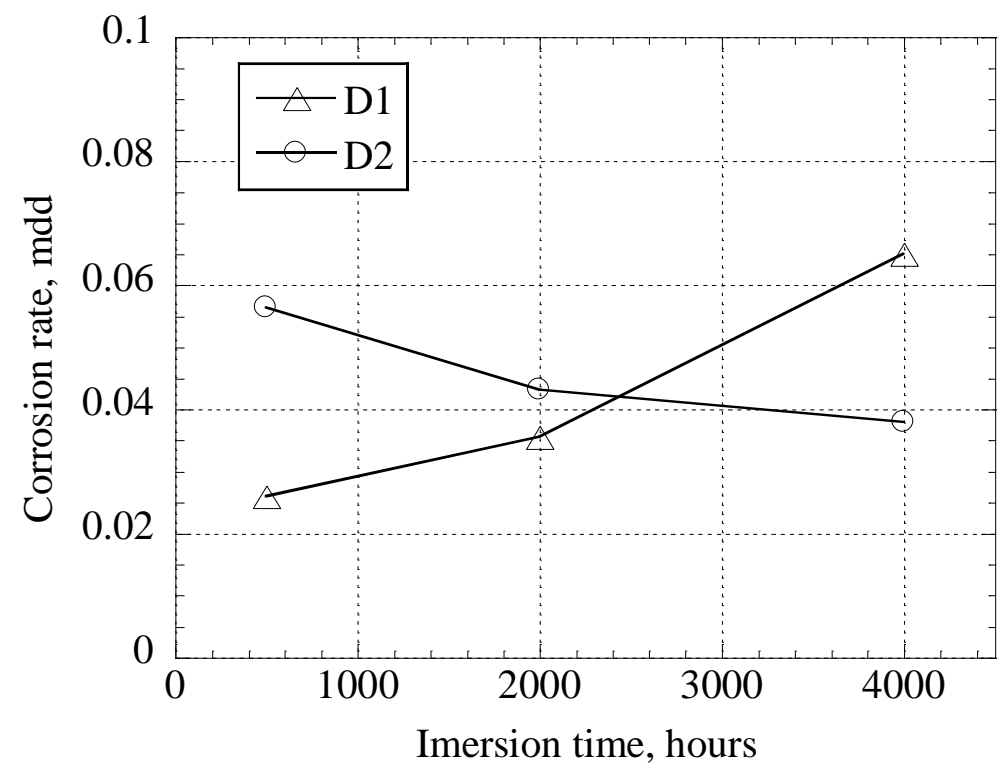

Fig. 2. Average corrosion rate of the specimens in the simulated geothermal water.

\subsection{Corrosion Potential and Passive Film}

Figure 3 shows the time variations of OCP (open circuit potential) of the D1 and D2 specimens in the test water. In the first few hours after the start of test, the two specimens showed almost the same values with a rising trend. However, from about 4 hours after the start of test and until the 20 hours measurement, the D2 specimen with the modified heat treatment exhibited stable and higher potentials than those of the D1 specimen with conventional heat treatment. It is considered that the specimen of $\mathrm{D} 2$ has better corrosion resistance than that of D1 in the simulated geothermal water. This behavior agrees with the above result obtained in the 4,000 hours immersion test.

The SEM images showing the surfaces of the specimens after 20 hours OCP measurements are given in Fig. 4. Compared with the specimen of D2, many large pits were clearly observed on that of D1. This result indicates that pitting corrosion occurred difficulty on the modified heat-treated material in the simulated geothermal water. It is assumed that the better corrosion resistance of the modified heat-treated material is related to the passive film formed in the test water. 


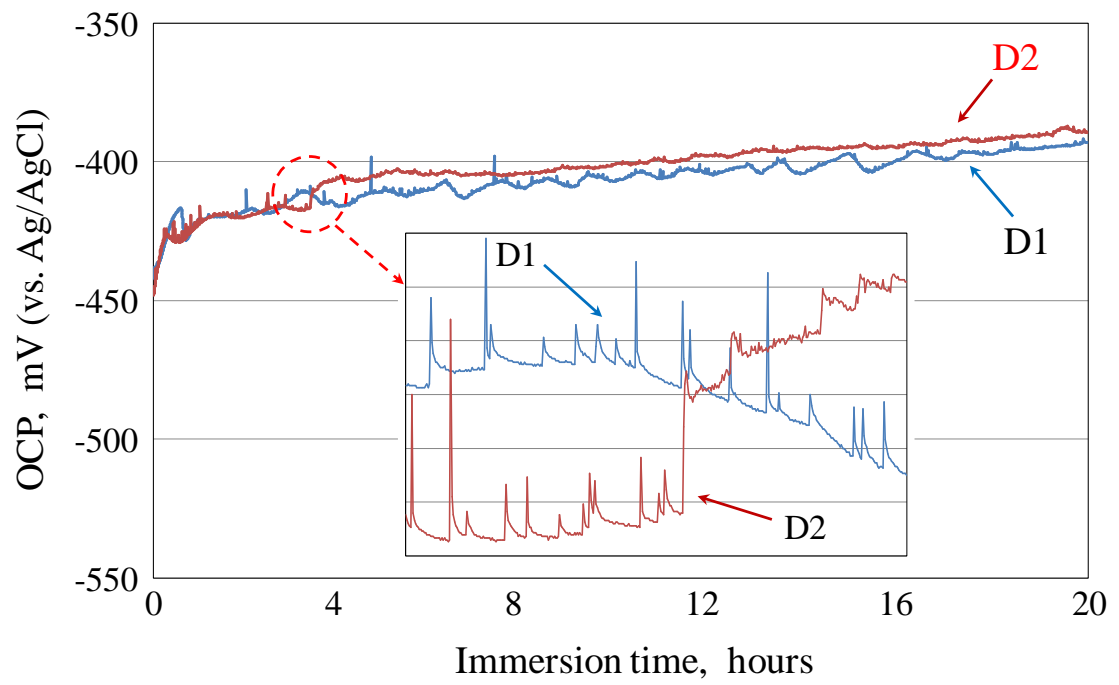

Fig. 3. Time variations of OCP of the D1 and D2 specimens in the test water.

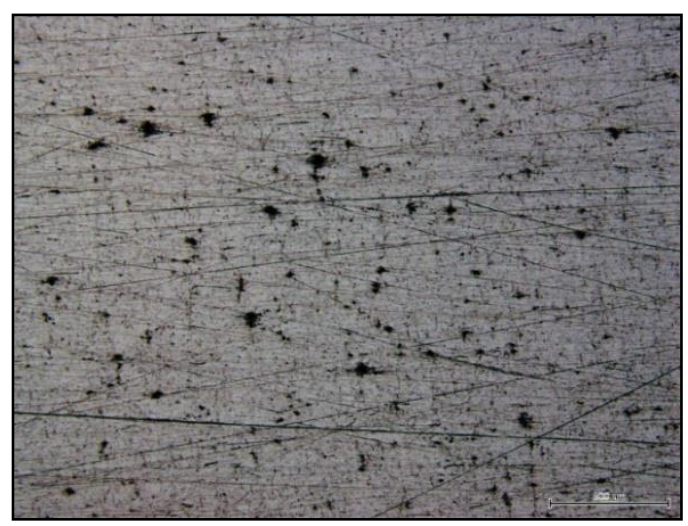

(a) D1 specimen

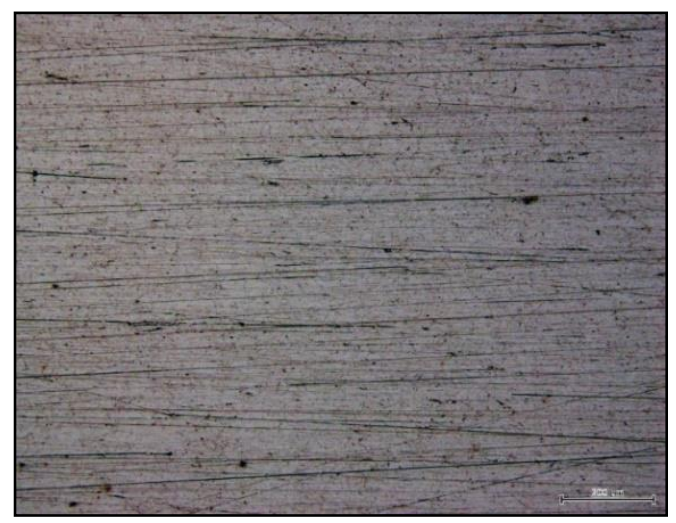

(b) D2 specimen

Fig. 4. SEM images showing the surfaces of the specimens after 20 hours OCP measurements.

The passive films formed on the two specimens in the 20 hours OCP measurements were investigated with XPS. From the peaks of cations appeared on the recorded XPS signals, the compositions of the passive films were analyzed. From the analysis results, it was confirmed that the films formed on the specimens of $\mathrm{D} 1$ and $\mathrm{D} 2$ consisted of $\mathrm{Cr}, \mathrm{CrOOH}, \mathrm{CrO}_{3}, \mathrm{Fe}, \mathrm{FeO}, \mathrm{Fe}_{2} \mathrm{O}_{3}$ and a little amount of $\mathrm{Cu}$ and $\mathrm{CuO}$. Furthermore, only in the film formed on the $\mathrm{D} 1$ specimen a little amount of $\mathrm{Ni}$ and $\mathrm{Ni}(\mathrm{OH})_{2}$ was detected. As an example, Fig. 5 shows the peak fitting of the recorded signals of $\mathrm{Fe}_{2} \mathrm{p}_{3 / 2}, \mathrm{Cr} 2 \mathrm{p}_{3 / 2}, \mathrm{Ni} 2 \mathrm{p}_{3 / 2}$ and $\mathrm{Cu} 2 \mathrm{p}_{3 / 2}$ in the film formed on the D1 specimen in the 20 hours OCP measurement. The depth profiles of the films formed on the specimens of D1 and D2 are shown in Fig. 6. It can be observed that the composition ratio of Cr-oxides $\left(\mathrm{CrOOH}, \mathrm{CrO}_{3}\right)$ in the outermost surface of the passive film of the $\mathrm{D} 2$ specimen was higher than that on the D1 specimen. This should be the reason why the specimen of D2 has better corrosion resistance than that of D1 in the simulated geothermal water.

Ishii et al. [21] have suggested that the $\mathrm{Cu}$ added in ferritic stainless steels promotes the enrichment of $\mathrm{Cr}$ concentration of passive films and reduces the anodic reactions. It is therefore considered that the formation of $\mathrm{Cr}$-enriched passive films was promoted by the $3.10 \mathrm{mass} \% \mathrm{Cu}$ added in the $16 \mathrm{Cr}-4 \mathrm{Ni}$ steel. However, it has been also reported that the precipitation of $\mathrm{Cu}$ particles deteriorates the corrosion resistance of the stainless steels [21]. It is well known that the improvement in strength of the precipitation hardening martensitic stainless steels contributes to the precipitation of $\mathrm{Cu}$ particles in the martensite matrix during aging treatments $[16,22]$. In other words, the $\mathrm{Cu}$ particles in the precipitation hardening martensitic stainless steels have not only the strengthening effect but also the demerit of deteriorating corrosion resistance. In this 
work, it is considered that the deteriorated corrosion resistance of the D1 specimen was due to the $\mathrm{Cu}$ particles precipitated by tempering at $580^{\circ} \mathrm{C}$ for 3 hours. On the other hand, Viswanathan et al. [16] have found that during aging at temperatures close to $600^{\circ} \mathrm{C}$, a certain amount of austenite formed at lath boundaries in the 17-4PH stainless steel. It has been reported that the reverted austenite drew more and more $\mathrm{Cu}$ from the martensite laths as the solubility of $\mathrm{Cu}$ in austenite is much higher, so that the martensite laths became depleted in $\mathrm{Cu}[16]$. For this reason, in this work it is presumed that a relatively small amount of $\mathrm{Cu}$ particles formed in the $\mathrm{D} 2$ material during the two-steps tempering treatments at the temperatures higher than $600^{\circ} \mathrm{C}$, so that the material showed better corrosion resistance in the test water. For the same reason, it is assumed that the $\mathrm{Ni}$ in the martensite laths decreased by the two-steps tempering treatments at the higher temperatures, so that no Ni-oxides was detected in the passive film formed on the D2 specimen [23, 24].

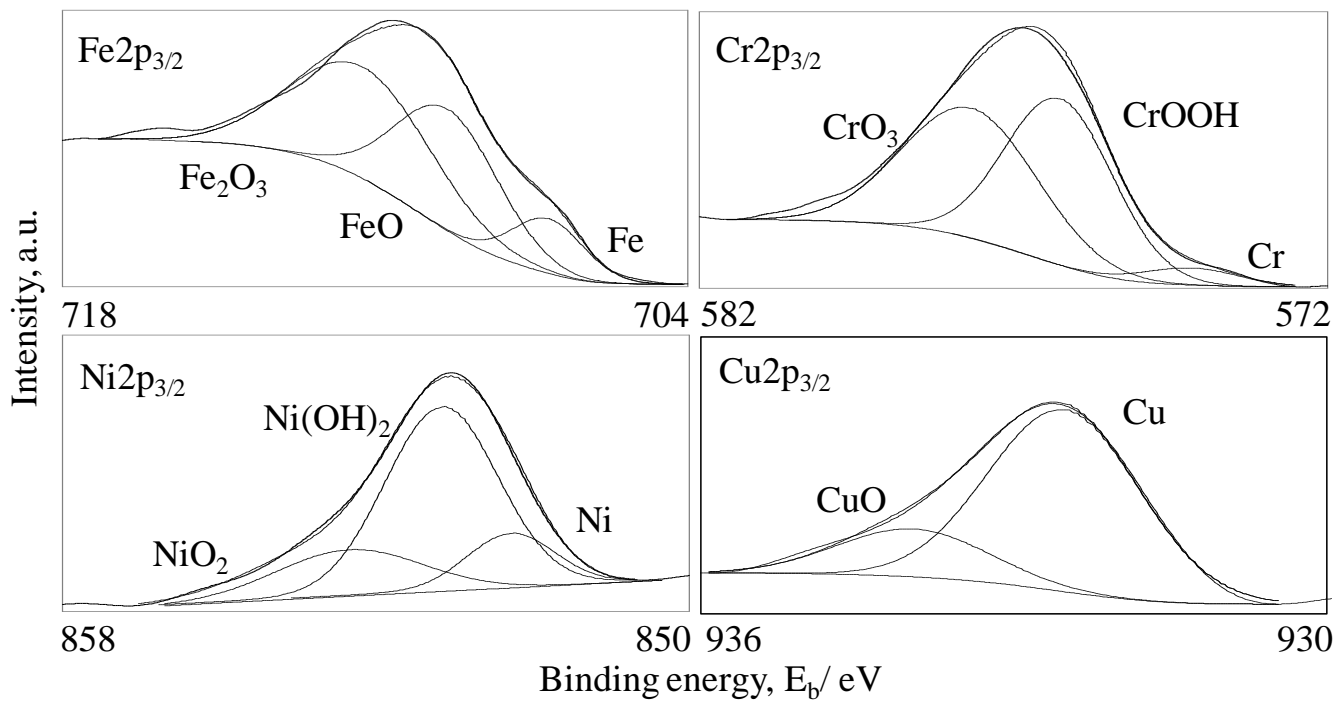

Fig. 5. Peak fitting of the recorded signals of $\mathrm{Fe} 2 \mathrm{p}_{3 / 2}, \mathrm{Cr} 2 \mathrm{p}_{3 / 2}, \mathrm{Ni} 2 \mathrm{p}_{3 / 2}$ and $\mathrm{Cu} 2 \mathrm{p}_{3 / 2}$ in the film formed on the D1 specimen in the 20 hours OCP measurement.

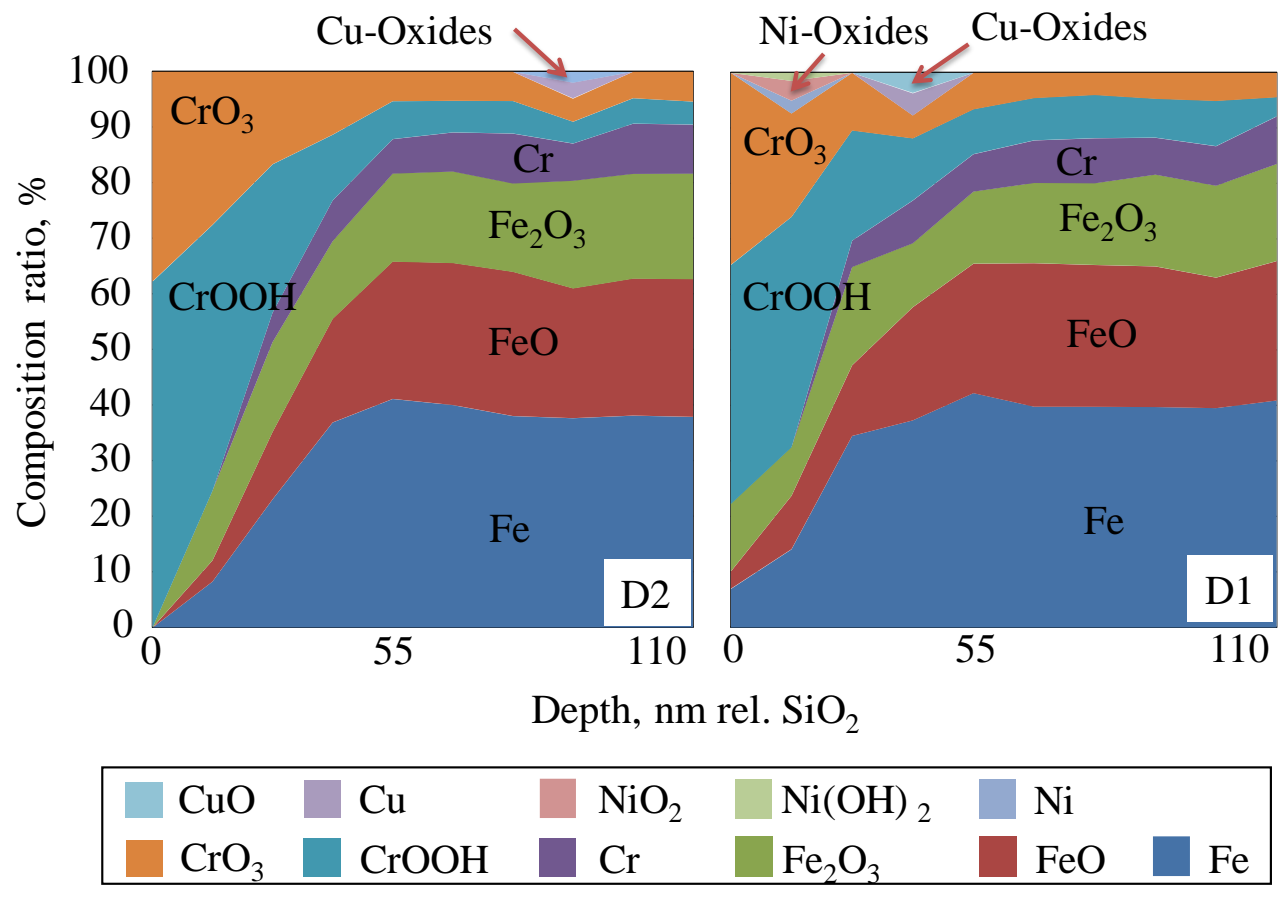

Fig. 6. Depth profiles of the films formed on the specimens of D1 and D2 in the 20 hours OCP measurement. 


\section{Summary}

In immersion corrosion tests up to 4,000 hours, the modified heat-treated material of $16 \mathrm{Cr}$ - $4 \mathrm{Ni}$ steel in the simulated geothermal water showed lower corrosion rates than those of the conventional heat-treated one. In the electrochemical corrosion tests, the modified heat-treated material exhibited noble and stable corrosion potential behavior. It is suggested that the modified heat-treated material has better corrosion resistance for a longer service term than the conventional heat-treated one.

From the XPS analysis results, it was made clear that the passive films formed on the specimens in the simulated geothermal water were consisted mainly of $\mathrm{Cr}$-oxides $\left(\mathrm{CrOOH}, \mathrm{CrO}_{3}\right)$ and $\mathrm{Fe}$-oxides $\left(\mathrm{FeO}, \mathrm{Fe}_{2} \mathrm{O}_{3}\right)$. Moreover, the composition ratio of Cr-oxides in the outermost surface of the passive film formed on the modified heat-treated material was higher than that on the conventional heat-treated one. It is assumed that the better corrosion resistance of the modified heat-treated material is related to the formation behavior of the Cr-enriched passive film.

\section{References}

[1] Y. Sakai, M. Yamashita, K. Shiokawa, L.-B. Niu, M. Kobayashi, and H. Takaku, "SCC growth behavior of materials for geothermal steam turbine," Zairyo-to-Kankyo, vol. 53, no. 3, pp. 143-148, 2004.

[2] Y. Sakai, M. Yamashita, K. Shiokawa, L.-B. Niu, M. Kobayashi, and H. Takaku, "Corrosion resistance of materials for geothermal steam turbines," in Proc. ICOPE-03, Kobe, Japan, 2003, pp. 3-297 - 3-302.

[3] H. Takaku, L.-B. Niu, H. Kawanishi, N. Takamura, K. Monma, Y. Sakai, M. Yamashita, and K. Shiokawa, "Corrosion behavior of steam turbine materials for geothermal power plants," in Proc. 14ICPWS, Kyoto, Japan, 2004, pp. 718 - 723.

[4] Y. Sakai, M. Y. Yamashita, and M. Sakada, "Geothermal steam turbines with high efficiency, high reliability blades," Geotherm. Res. Counc. Trans., vol. 24, pp. 521-526, 2000.

[5] H. Kato, K. Shiokawa, and Y. Sakai, "Characteristic evaluation of erosion and corrosion resistance of coating materials for geothermal steam turbine," Turbomacbinery, vol. 30, pp. 599-606, 2004.

[6] L.-B. Niu, H. Ishitake, S. Izumi, K. Shiokawa, M. Yamashita, and Y. Sakai, "Stress corrosion cracking behavior of hardening-treated 13Cr stainless steel," IOP Conf. Ser.: Mater. Sci. and Eng., vol. 317, p. $012073,2018$.

[7] O. Jonas, "Steam turbine corrosion," Mater. Perform., vol. 24, pp. 9-18, 1985.

[8] O. Jonas and L. Machemer, "Steam turbine corrosion and deposits problems and solutions," in Proc. 37th Turbomachinery Symposium, Houston, USA, 2008, pp. 211-228.

[9] C. W. Sun, R. Hui, W. Qiu, and S. Yick, "Progress in corrosion resistant materials for supercritical water reactors," Corros. Sci., vol. 51, pp. 2508-2523, 2009.

[10] S. Roychowdhuy, V. Kain, M. Gupta, and R. C. Prasad, "IGSCC crack growth in simulated BWR environment - effect of nitrogen content in non-sensitised and warm rolled austenitic stainless steel," Corros. Sci., vol. 53, pp. 1120-1129, 2011.

[11] F. Meng, Z. Lu, T. Shoji, J. Wang, E. Han, and W. Ke, "Stress corrosion cracking of uni-directionally cold worked 316NG stainless steel in simulated PWR primary water with various dissolved hydrogen concentrations," Corros. Sci., vol. 53, pp. 2558-2565, 2011.

[12] G. V. Prabhu Gaunkar, A. M. Huntz, and P. Lacombe, "Role of carbon in embrittlement phenomena of tempered martensitic 12Cr-0.15\%C steel," Met. Sci., vol. 14, pp. 241-252, 1980.

[13] T. Ozaki and Y. Ishikawa, "Stress corrosion cracking susceptibility and cracking criteria of $13 \mathrm{Cr}$ martensitic stainless steels in neutral chloride solution at room temperature," Tetsu-to-Hagane, vol. 75, pp. 1201-1208, 1989.

[14] T. Ozaki and Y. Ishikawa, "Stress corrosion cracking in high temperature-high purity water and selective corrosion of nickel-bearing 13Cr stainless steels," J. Jpn. Inst. Met., vol. 52, pp. 852-858, 1988.

[15] T. Ozaki and Y. Ishikawa, "Stress corrosion cracking of nickel containing 13Cr stainless steels in high temperature-high purity water," Boshoku Gijutsu, vol. 38, pp. 148-154, 1989.

[16] U. K. Viswanathan, S. Banerjee, and R. Krishnan, "Effects of aging on the microstructure of 17-4 PH stainless steel,” Mater. Sci. Eng., vol. A104, pp.181-189, 1998.

[17] M. Murayama, Y. Katayama, and K. Hono, "Microstructural evolution in a $17-4 \mathrm{PH}$ stainless steel after aging at $400^{\circ} \mathrm{C}$," Metall. Mater. Trans., vol. 30A, pp. 345-353, 1999. 
[18] H. Nagano, M. Yamashita, and H. Uchida, "Chapter 2. Forms of corrosion," in Kankyo Zairyo Gaku (Environmental Materials Science) (in Japanese). Tokyo, Japan: Kyoritsu Shuppan, 2004, pp. 9-12.

[19] C. D. Wagner, W. M. Riggs, L. E. Davis, J. F. Moulder, and G. E. Mullenberg, Handbook of X-ray Photoelectron Spectroscopy. Perkin-Elmer Corp., Eden Prairie, 1979.

[20] Japan Society of Corrosion Engineering. "Chapter 6. Corrosion Test Method," in Corrosion Handbook (in Japanese). Tokyo, Japan: Maruzen, 2000, pp. 569-573.

[21] T. Ishii, T. Ujiro, E. Hamada, S. Ishikawa, and Y. Kato, "A mechanism of improvement in the corrosion resistance of ferritic stainless steels by Cu addition," Tetsu-to-Hagane, vol. 97, pp. 441-449, 2011.

[22] Y. Nagataki, K. Sato, and Y. Hosoya, "Precipitation hardening and mechanical properties in Cu added martensitic ultra-high strength steels," Tetsu-to-Hagane, vol. 94, pp. 553-561, 2008.

[23] H. J. Jang and H. S. Kwon, "In situ study on the effects of Ni and Mo on the passive film formed on Fe-20Cr alloys by photoelectrochemical and Mott-Schottky techniques," J. Electroanalytical Chem., vol. 590, pp. 120-125, 2006.

[24] V. Shankar Rao and L. K. Singhal, "Corrosion behavior and passive film chemistry of 216L stainless steel in sulphuric acid," J. Mater. Sci., vol. 44, pp. 2327-2333, 2009. 